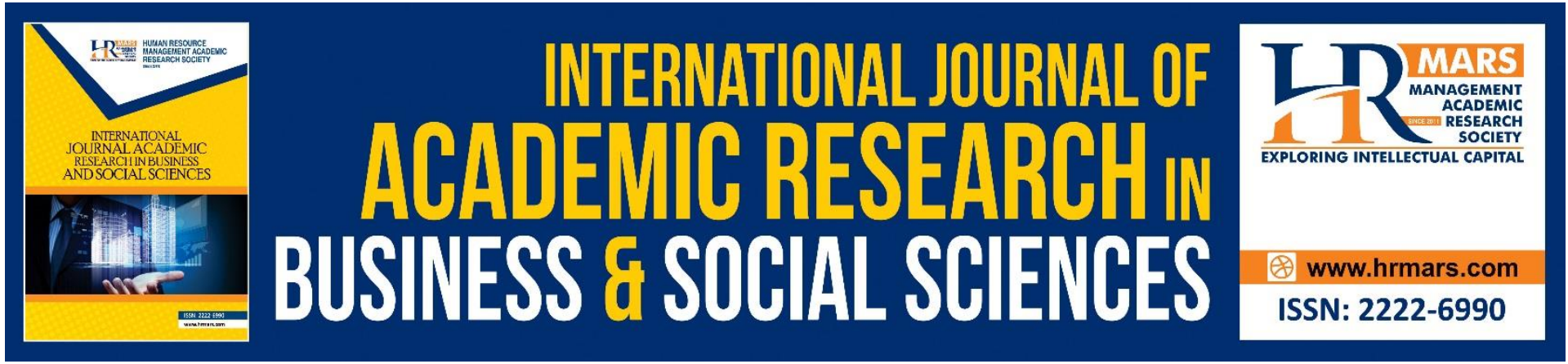

\title{
Teaching Methods Used by Tamil School Physical Education Teachers
}

Kalaivanee Chinanapan, Gunathevan Elumalai, Doewes Rumi Iqbal, Fariba Hossein Abadi \& Mohansundar Sankaravel

To Link this Article: http://dx.doi.org/10.6007/IJARBSS/v11-i7/10564

DOI:10.6007/IJARBSS/v11-i7/10564

Received: 17 May 2021, Revised: 20 June 2021, Accepted: 09 July 2021

Published Online: 29 July 2021

In-Text Citation: (Chinanapan et al., 2021)

To Cite this Article: Chinanapan, K., Elumalai, G., Iqbal, D. R., Abadi, F. H., \& Sankaravel, M. (2021). Teaching Methods Used by Tamil School Physical Education Teachers. International Journal of Academic Research in Business and Social Sciences, 11(7), 978-983.

Copyright: (c) 2021 The Author(s)

Published by Human Resource Management Academic Research Society (www.hrmars.com)

This article is published under the Creative Commons Attribution (CC BY 4.0) license. Anyone may reproduce, distribute, translate and create derivative works of this article (for both commercial and non-commercial purposes), subject to full attribution to the original publication and authors. The full terms of this license may be seen

at: http://creativecommons.org/licences/by/4.0/legalcode

Vol. 11, No. 7, 2021, Pg. 978 - 983

Full Terms \& Conditions of access and use can be found at http://hrmars.com/index.php/pages/detail/publication-ethics 


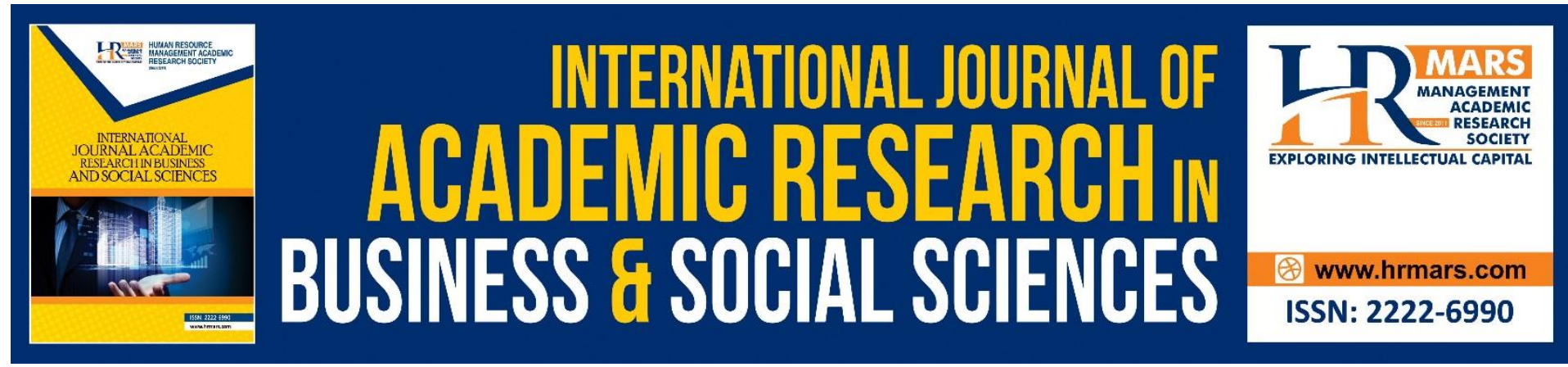

\title{
Teaching Methods Used by Tamil School Physical Education Teachers
}

\author{
Kalaivanee Chinanapan, Gunathevan Elumalai, Doewes Rumi \\ lqbal, Fariba Hossein Abadi \& Mohansundar Sankaravel \\ University Pendidikan Sultan Idris, Universitas Sebelas Maret, Indonesia \\ Email: gunathevan@fsskj.upsi.edu.my
}

\begin{abstract}
This study was conducted to identify teaching methods used by Bagan Datuk District Tamil schools' physical education teachers. Quantitative approach with a one-shot case study design was used for this study. Total of 60 physical education teachers from the Bagan Datuk district were chosen using the purposive sampling method as respondents. A simple questionnaire developed by the researcher was used in this study to collect the data. The data were analyzed descriptively. The results showed that $66.7 \%$ of PE teachers apply the instructional method, $25 \%$ use the regular game's strategy, and $5 \%$ use the modified game's method. Analysis based on gender showed there were no significant differences. Both men and women teachers prefer to teach using traditional methods. Most of them said it's easy to teach in the traditional way rather than new methods because of no exam for physical education. In conclusion, most of the Tamil schools' Physical Education teachers are familiar with the instructional method. Therefore, multi-approach must be maximized in Physical Education classes to enhance pupils' physical activity and wellness achievement.
\end{abstract}

Keywords: Physical Education, Regular Games, Instructional Method, Modified Games \& Multi-approach

\section{Introduction}

Education can be labeled as a systematic process that involves planning, preparing, applying, and evaluating phases to improve an individual's performance, especially in their behavior. Usually, teaching is defined as a considerate, planned, and systematic process of acquiring specific knowledge, skills, and behavior (Perez-Pueyo et al., 2020). Since the importance was given to the educational system globally, it is not surprising that a vast amount of research focused on teaching methods enables Education to fulfill its aims. A good education concerns many elements such as strategy, approach, technique, and materials is the key factor in making an effective teaching lesson (Hirsh et al., 2020).

Physical Education is one of the main subjects focused at the primary and secondary school levels. According to the National Educational Philosophy, Physical Education is a crucial element to produce a holistic individual. Mungure (2017) stated that the teacher plays a vital role in providing a suitable learning environment with various activities. Also, Rainer and Jarvis 
(2020) proved that PE teachers play a pivotal role in creating the appropriate learning environment and maximizing the involvement of pupils. Based on the transformation of the curriculum made by the Ministry of Education in Malaysia (2011), Primary School Standard Curriculum (KSSR) was introduced. It mainly ensures that pupils have relevant knowledge, skills, and behavior to face the challenges in upcoming years, fully manipulated by science and technology (Paramasivam \& Ratnavadivel, 2018).

KSSR has highlighted four principles: an integrated approach, educational opportunity for pupils, individual development, and lifelong Education (Ministry of Education Malaysia, 2010). Thus, implementing a new curriculum is compulsory in all the subjects, especially in Physical Education, to enhance pupils' achievement and performance. In this $21^{\text {st }}$-century learning environment, teachers can use various teaching methods to deliver skills and knowledge to the pupils, especially in Tamil schools.

Priority for physical education classes has been eradicated from the school schedule in many schools. Most schools mainly focused on enhancing academic performance compared to physical fitness, which caused limited time spent in physical education learning sessions (Gumbo, Magonde \& Nhamo, 2017). The Physical Education Teacher plays an essential role in creating multiple pedagogical approaches that lead pupils to respond positively (Opstoel et al., 2019). Hence, the multiple methods in physical education lead to producing a holistic individual who can face the upcoming challenges (Cain, 2020). According to Keiler (2018), the teaching sessions' methods or strategies are likely linked to the pupil's performance in sports and academics. Thus, the researcher conducted a simple survey to identify the teaching strategy and approach implemented in physical Education among physical education teachers by gender in Tamil schools in the Bagan Datuk district.

\section{Method}

Sixty (60) Tamil Primary School Physical Education teachers have participated in this study. Twenty-eight (28) male and thirty-two (32) female respondents were chosen by the purposive sampling method. The participant's views on the teaching method used during PE classes were identified using a simple questionnaire developed by the researcher. The questionnaire has demographic characteristics, method selections such as strategy, and the approach used in PE classes. All participants were informed about the aim of the study and agreed to take part without any conditions. Collected data were analysed descriptively. Findings of this study were reported based on numbers ( $\mathrm{n}$ ) and percentages (\%).

\section{Results}

Based on the data shown in Table 3.1 below, 40 among 60 Physical Education Tamil school teachers (66.7\%) in the Bagan Datuk district use the instruction method, while 15 are using the traditional game method (25\%), and five are using modified games $(8.3 \%)$ to teach physical education. 
Table 3.1

Results of the survey among 60 PE teachers

\begin{tabular}{lcc}
\hline Method & Number of Teachers & Percentage \% \\
\hline Instruction & 40 & $66.7 \%$ \\
Regular games & 15 & $25 \%$ \\
Modified games & 5 & $8.3 \%$ \\
\hline
\end{tabular}

The analysis based on gender (table 3.2) showed no significant differences in the teaching method of physical education among Tamil school PE teachers in Bagan Datuk district, where $50 \%(n=20)$ of male and $50 \%(n=20)$ of female teachers use the instruction method. Besides, $53 \%(n=8)$ of male and $47 \%(n=7)$ of female teachers use the regular game method during PE classes. Also, $40 \%(n=2)$ of male teachers and $60 \%(n=3)$ of female teachers use the modified game method to teach physical education.

Table 3.2

Analysis based on gender

\begin{tabular}{lcccc}
\hline Method & \multicolumn{4}{c}{ Number of Teachers } \\
\cline { 2 - 5 } & Male & \% Male & Female & \% Female \\
\hline Instruction & 20 & $50 \%$ & 20 & $50 \%$ \\
Regular games & 8 & $53 \%$ & 7 & $47 \%$ \\
Modified games & 2 & $40 \%$ & 3 & $60 \%$ \\
\hline
\end{tabular}

\section{Discussion}

This study aimed to identify the teaching approach used by Primary Tamil schools Physical Education teachers in the Bagan Datuk district. The results revealed that the Tamil schools PE teachers who worked in the Primary school of Bagan Datuk district used the command and traditional approach the most and modified game the least. This proved that the PE teachers using teacher rather than student-centered teaching approach in physical education lessons. In addition, the result showed that most teachers are not familiar with using various methods effectively due to inadequate knowledge in teaching Physical Education, lack of school facilities, and lack of time allocation. The present study was similar to Nikravan et al. (2019), who reported that Iran PE teachers primarily use the traditional approach in their lessons.

A similar result was revealed in the research of Yildiz and Karakullukcu (2019). They stated that most PE teachers in public and private schools in Turkey use a teacher-centered teaching approach. On the other hand, Bessa et al.(2021) identified the effects of two different teaching strategies, such as Traditional Teaching and the Sport Education model, on students' empowerment and self-confidence in high school PE classes in Northern Portugal. The research findings revealed that the traditional approach was ineffective in improving high school students' empowerment and self-confidence. Overall, this study proved that there are few teaching methods only applied in Physical Education. The instructional method made 
their teaching easier. Gender does not influence the teaching method used among Tamil school PE teachers in the Bagan Datuk district.

\section{Conclusion}

In conclusion, the PE teachers were unable to structure an effective activity according to the topic given. Several teaching styles were highlighted among Tamil school PE teachers in recent decades. Verbal presentation is one of them, and it's defined as an instruction method that limits the teacher during the physical education class session. Most of the teachers are giving a speech or long instruction during the class. It results in using the teachercantered method during PE classes. The instruction strategy has a weakness in Physical Education teaching; instead, it is limited to theory learning and turns students into passive learners, resulting in a lack of enjoyment. The new era focused on student centered learning method through varies strategies such as collaborative learning, cooperative learning, modular learning, inquiry method and so on. The Physical Education teachers should masters themselves in the latest approach towards a successful learning process and make the students enjoy their activities and enhance knowledge and skills in physical education.

\section{Correspondent Author}

Gunathevan Elumalai

Faculty of Sports Science and Coaching, University Pendidikan Sultan Idris.

Email: gunathevan@fsskj.upsi.edu.my

\section{Reference}

Bessa, C., Hastie, P., Rosado, A., \& Mesquita, I. (2021). Sport Education and Traditional Teaching: Influence on Students' Empowerment and Self-Confidence in High School Physical Education Classes. Sustainability, 13(2), 578. https://doi.org/10.3390/su13020578.

Cain, C. M. (2020). Understanding the Use of Learner-Centered Teaching Strategies by Secondary Educators [Doctoral Dissertation, Walden University]. Scholarworks. https://scholarworks.waldenu.edu/dissertations.

Hirsh, S., Nilholm, C., Roman, H., Forsberg, E., \& Sundberg, D. (2020). Reviews of teaching methods - which fundamental issues are identified? Education Inquiry, 1-20. https://doi.org/10.1080/20004508.2020.1839232

Gumbo, S., Magonde, S., \& Nhamo, E. (2017). Teaching Strategies Employed by Physical Education Teachers in Gokwe North Primary Schools. International Journal of Sport, Exercise and Health Research, 1(2), 61-65. https://doi.org/10.31254/sportmed.1203

Keiler, L. S. (2018). Teachers' roles and identities in student-centered classrooms. International Journal of STEM Education, 5(1), 1-20. https://doi.org/10.1186/s40594018-0131-6.

Ministry of Education Malaysia. (2010). Explanations Book for Standard Based Primary School Curriculum. Putrajaya: Curriculum Development Division.

Nikravan, M., Safania, A. M., \& Zarei, A. (2019). Physical Education Method: Effects on Physical Fitness and Competency of the Students. Annals of Applied Sport Science, 7(4), 17-26. https://doi.org/10.29252/aassjournal.698

Mungure, D. M. (2017). An Investigation of the Teaching Approach Used by Tutors to Prepare Science and Mathematics Teachers during Training at Morogoro Teachers' College. Journal of Education and Practice, 8(6), 68-71. 
https://files.eric.ed.gov/fulltext/EJ1133089.pdf

Opstoel, K., Chapelle, L., Prins, F. J., de Meester, A., Haerens, L., van Tartwijk, J., \& de Martelaer, K. (2019). Personal and social development in physical education and sports: A review study. European Physical Education Review, 26(4), 797-813. https://doi.org/10.1177/1356336×19882054

Perez-Pueyo, N., Hortiguela-Alcala, D., Hernando-Garijo, A., \& Granero-Gallegos, A. (2020). The Attitudinal Style as a Pedagogical Model in Physical Education: Analysis of Its Effects on Initial Teacher Training. International Journal of Environmental Research and Public Health, 17(8), 2816. https://doi.org/10.3390/ijerph17082816

Rainer, P., \& Jarvis, S. (2020). Primary physical education but not of primary importance secondary PE teachers perceptions of the role of primary PE. Journal of Education, 3(13), 1-14. https://doi.org/10.1080/03004279.2020.1820549

Paramasivam, T., \& Ratnavadivel, N. (2018). Issues and challenges in managing curriculum change in primary schools: A case study of managing Year Four History Curriculum in the District of Kuala Selangor, Malaysia. Journal Of Research, Policy \& Practice of Teachers \& Teacher Education, 8(1), 18-31. https://doi.org/10.37134/jrpptte.vol8.no1.3

Yıldız, M., \& Karakullukcu, M. F. (2019). Physical Education Teachers' Using of Teaching Styles Levels and Their Perceptions Towards Styles in Public and Private Schools in Turkey. World Journal of Education, 9(4), 41. https://doi.org/10.5430/wje.v9n4p41 